\title{
Goethe's World Literature, Universal Particularism, and European Imperialism
}

\author{
Dongho Cha \\ University of Illinois Chicago
}

Follow this and additional works at: https://docs.lib.purdue.edu/clcweb

ర

Part of the Comparative Literature Commons, and the European Languages and Societies Commons

Dedicated to the dissemination of scholarly and professional information, Purdue University Press selects, develops, and distributes quality resources in several key subject areas for which its parent university is famous, including business, technology, health, veterinary medicine, and other selected disciplines in the humanities and sciences.

CLCWeb: Comparative Literature and Culture, the peer-reviewed, full-text, and open-access learned journal in the humanities and social sciences, publishes new scholarship following tenets of the discipline of comparative literature and the field of cultural studies designated as "comparative cultural studies." Publications in the journal are indexed in the Annual Bibliography of English Language and Literature (Chadwyck-Healey), the Arts and Humanities Citation Index (Thomson Reuters ISI), the Humanities Index (Wilson), Humanities International Complete (EBSCO), the International Bibliography of the Modern Language Association of America, and Scopus (Elsevier). The journal is affiliated with the Purdue University Press monograph series of Books in Comparative Cultural Studies. Contact: <clcweb@purdue.edu>

\section{Recommended Citation}

Cha, Dongho. "Goethe's World Literature, Universal Particularism, and European Imperialism." CLCWeb: Comparative Literature and Culture 17.4 (2015): <https://doi.org/10.7771/1481-4374.2720>

This text has been double-blind peer reviewed by $2+1$ experts in the field.

The above text, published by Purdue University Press @Purdue University, has been downloaded 791 times as of $11 /$ $07 / 19$.

This document has been made available through Purdue e-Pubs, a service of the Purdue University Libraries. Please contact epubs@purdue.edu for additional information.

This is an Open Access journal. This means that it uses a funding model that does not charge readers or their institutions for access. Readers may freely read, download, copy, distribute, print, search, or link to the full texts of articles. This journal is covered under the CC BY-NC-ND license. 


\section{PURDUE}

UNIVERSITY PRESS <http://www.thepress. purdue.edu>

\section{CLCWeb: Comparative Literature and Culture}

ISSN 1481-4374 <http://docs.lib.purdue.edu/clcweb> Purdue University Press (CPurdue University

CLCWeb: Comparative Literature and Culture, the peer-reviewed, full-text, and open-access learned journal in the humanities and social sciences, publishes new scholarship following tenets of the discipline of comparative literature and the field of cultural studies designated as "comparative cultural studies." In addition to the publication of articles, the journal publishes review articles of scholarly books and publishes research material in its Library Series. Publications in the journal are indexed in the Annual Bibliography of English Language and Literature (Chadwyck-Healey), the Arts and Humanities Citation Index (Thomson Reuters ISI), the Humanities Index (Wilson), Humanities International Complete (EBSCO), the International Bibliography of the Modern Language Association of America, and Scopus (Elsevier). The journal is affiliated with the Purdue University Press monograph series of Books in Comparative Cultural Studies. Contact: <clcweb@purdue.edu>

\section{Volume 17 Issue 4 (December 2015) Article 1 Dongho Cha, \\ "Goethe's World Literature, Universal Particularism, and European Imperialism" <http://docs.lib.purdue.edu/clcweb/vol17/iss4/1> \\ Contents of CLCWeb: Comparative Literature and Culture 17.4 (2015) \\ <http://docs.lib.purdue.edu/clcweb/vol17/iss4/>}

Abstract: In his article "Goethe's World Literature, Universal Particularism, and European Imperialism" Dongho Cha tracks the ideology in Goethe's concept of "world literature." Early comparatists claim to stand for the universalism of this concept by understanding it to totalize all literatures across linguistic, territorial, and national boundaries and intended to go beyond European nationalism. Cha argues that Goethe's idea of world literature is not a universal category that includes all of the world nliteratures, but a limited category that includes European literatures only and posits that world literature's and comparative literature's universalism is related to nineteenth-century European imperialism. Contrary to the paradigm of world literatures as practiced in comparative literature, Cha argues that the building and the politics and practice of world literature understood as world literatures must be characterized by boundlessness and limitlessness in order to achieve an understanding and practice of the universal and planetary. 


\section{Dongho CHA}

\section{Goethe's World Literature, Universal Particularism, and European Imperialism}

As a discipline, comparative literature is often traced Goethe's concept of "world literature" (Weltliteratur). This idea is not just to study literary works from all over the world; rather, it is to hold together all the literatures of the world as a totality, one that will transcend national and linguistic boundaries (see, e.g., Chow, World Target 71). Despite its cosmopolitan vision, however, the universalist politics of early European comparativism was not always successful. The process of comparison actually occurs whenever two or more concepts or ideas - such as national languages and literatures, geographical regions, authors, and themes - are juxtaposed. It just shows the situation that two or more objects of study are crossed, but does not clarify "what the gesture of comparing consists in, amount to, indeed realizes and reinforces" (Chow, World Target 72). For example, the notions of comparison like "diverse," "global," "international," and "transnational" seem to have the aspiration of "more than one," of inclusive multicultural universalism going beyond restrictive national particularism. Nevertheless, there is something paradoxical in this, for national particularities are already "more than one" and nationalism refers to the process when Europe as a single "province" is divided into individual nation states and hence from the outset the mechanisms of nationalism include the principle of pluralism. If so, then comparativist multiculturalism could not be constituted as a proper alternative to nationalisms and national literatures. Rather, it could aid and abet the ideology of nationalist rivalry and antipathy by failing to question the historical construction of nations and national identities because if comparativism is merely to parallel two or more national categories without reflection on the condition of possibility for the emergence of them, then it could admit or even strengthen the cultural separation between nations: "the enlightened beliefs in universals ... proceeds hand in hand with, or is the mere flip side of, the perpetuation and enforcement of cultural boundaries" (Chow, "Inscrutable" 69).

It is therefore dangerous to adhere to multicultural comparative literature as an alternative to narrow-minded nationalisms and national literatures. Cultural pluralism could probably become the rhetorical strategy to help to develop exclusive particularism. Then, multicultural comparative literature probably leads not so much to an intercultural equivalence as to asymmetrical relationship between national cultures. I posit that instead the task is to unmask ideological implications of peaceful and harmonious "universalism" of comparative literature. Indeed, early European comparatists focused on the cultural superiorities of their own nations and it is striking that even while ideas of universal literary roots were being discussed, comparisons were being made that involved evaluating one culture higher than another (see Bassnett 20). Comparative literature could as easily be manipulated to consolidate repressive cultural interests as they could be used to open up new intellectual avenues (see Chow, "Comparative Literature" 108). But the ambiguous "universal-particularism" of comparative literature is not attributable to the gap between the ideal and the real. Such a universalist discourse as comparative literature fundamentally has some formal structures leaving particularity behind.

There are many different kinds of particularities, but "culture" is by definition the most quintessential particularism since culture is defined as the set of values or practices of parts smaller than the whole: "culture is what some persons feel or do, unlike others who do not feel or do the same things" (Wallerstein 91). Thus, one particular culture functions to define a unique way of living within a group, as well as to show the difference or opposition of life-styles between groups. For example, quarrels for cultural hegemony arise between two cultural categories are understood as their own value and system. But how could one group justify its cultural system of values and practices in its own right? They actually do not have any essential and natural relation to the group. Values and practices have been constructed historically by numerous institutional and discursive operations. Particular groups, therefore, should take ideological and actions in order to declare some "arbitrary" set of cultural values and practices physical as being desirable and worthwhile: "there can be no justification of cultural values and/or practices other than by reference to some presumably universal or universalist criteria" (Wallerstein 91). Paradoxically, it is the very logic of universalism that justifies a certain particular culture. The nation, as Benedict Anderson puts it, is an "imagined community." It has not come from basic human nature, but created in the modern age by the intentional processes of the development of print-capitalism, the use of vernacular language, and the spread of daily newspapers: "nationalism is not the awakening of nations to self-consciousness: it invents nations where they do not exist" (Gellner 169). Anderson explores how national common language, territory, economy, and culture has been invented and created. A nation is "imagined" as a community, because regardless of the actual inequality and exploitation that may prevail in each, the nation is always conceived as a deep, horizontal comradeship. Ultimately it is this community that made it possible over the past two centuries for so many millions of people, not so much to kill, as willingly to die for such limited imaginings (Anderson 7).

National communities are regarded as a family sharing a common fate. The qualities and properties of each member are not important. Whether they are men or women, rich or poor, smart or stupid, they are all national people. If the nation were a unitary community to start with, it had not needed to be constructed through complex institutional and discursive operations. There are in reality a great many qualitatively heterogeneous elements in the nation and this is the reason why the nation should be imagined as a community. Otherwise it is impossible to model "nation-ness" to construct a community organic enough for people to willingly lay down their lives in behalf of their own nations (Anderson 139). The point in nation building is to bind together disparate elements into one national whole and Anderson insists that especially the newspaper make this type of holding together possible. By arranging random collections of social and individual events, apparently unrelated to one another in chronological order, it fosters belief that a solid community moves through the homogeneous, empty time of 
history. When reading newspaper articles, now national people "think of the representative body, not the personal life" (Anderson 32) - in short, "us" as belonging to the same community. If so, then our concern is the formal dimension of newspaper.

Universalism plays a large part in the background of the newspaper's representative function. In order to put a variety of events in linear time, newspaper should reduce all the qualitative and intrinsic differences among events to the state of Identity where they are homogenized into the constituent units of national community. But such a violent and repressive process of homogenization is not an easy task: it is only able to succeed when based on a universalist logic. Indeed, one never choses nation and nationality: one is just born and raised in one country. One's nation or nationality is, in this manner, determined by the universal references, like land, kinship, and tongue. For example, "motherland," "fatherland," "race," "blood," and "language" are principal categories of forming an inevitable link between nation and people. These "natural" references become the most fundamental criteria for membership of national community and uiversalism makes possible collectives to be organic national communities by bridging the gap between class, gender, wealth, religion, etc. Once again, it is the very logic of universalism that justifies a certain particular culture. The contradiction of nationalism is, as Fredric Jameson points out based on Partha Chatterjee's argument, "the attempt to universalize a particularity" (Jameson, "Globalization" 66). Certainly, there seems to be a binary opposition between the particular and the universal, and thus it seems to be contradictory that national Particularism is involved in Universalism. Nevertheless, the coexistence of the particular and the universal is not necessarily contradictory: if it were contradictory, it would be "dialectically" contradictory in the Hegelian sense (see Jameson, "A Note"). Rather, universal particularism is the fundamental structural feature of nationalism and national culture because its role is to attach people to a nation and simultaneously differentiate the nation from others. For instance, a certain cultural category looks like universal to the interior inhabitants, whereas it looks like particular to the exterior inhabitants. More specifically, on the level of nation national culture functions to bind together heterogeneous elements into the single national group, while on the level of the global it functions to distinguish national groups from one another. It is the viewer's inter-relational, situational position and not the transcendent separatism to determine the precise relation between the particular and the universal. For this reason, Jameson argues that the theoretical tension between the two in national culture "does not have to do with Difference so much as with where it is located or positioned" ("Notes" 74). The particular and the universal do not confront each other across a chasm, but exist on the common ground where the particular turns into the universal and the universal back into the particular from moment to moment. Hence, universalism could not be the ultimate alternative to particularism.

Generally, universalism is proposed as the solution to the problematics of particularism and universalist appeals like comparative literature not only escape from the problematics of particularism, but also suggest an alternative promising the peaceful coexistence of different cultures and traditions. However, it is nothing but ideological deception that the universal would integrate dialectically the particular into the same whole completely. As I posit previously, a national culture is at once particular and universal and the two are connected to each other, as well as maintain a non-contradictory "immanent" relationship: "contrary to what has been advertised by both sides, universalism and particularism reinforce and supplement each other; they are never in real conflict ... Universalism and particularism endorse each other's defect in order to conceal their own; they are intimately tied to each other in their accomplice. In this respect, a particularism such as nationalism can never be serious critique of universalism" (Sakai 106). The point is, again, that the particular and the universal could only exist in relation to each other: the particular could exist only as a being constituted on the basis of the universal and the reverse holds true as well. Thus, the universalist claims of nineteenth-century European comparative literature could hardly be an alternative model for nationalism and national literature without theoretical reflection on the immanent relationship between the particular and the universal: particularist national literature and universalist comparative literature are most likely to coexist on one and the same plane of immanence. If so, then comparative literature could not overcome nation-centrisms because as pointed out by Naoki Sakai it provides the condition of the ontological possibility for national literatures.

Goethe's paradigm of world literature includes the notion that "national literature is no longer of importance; it is time for world literature" (Goethe, Essays 224) and this means that the phenomenon which he designated as "world literature" would come about mainly when the disputes within one nation are settled by the opinions and judgments of others. Early comparatists claimed to stand for the universalist principles of world literature, which aims at totalizing global literary works across linguistic, territorial, and national particularities: world literature serves to promote "a traffic in ideas between peoples, a literary market to which the nations bring their intellectual treasures for exchange" (Strich 13) and this Goethean literary universalism seemed to go beyond the one-sidedness and narrow-mindedness of European nationalisms and national literatures. According to John Pizer, Goethe's world literature and its pacifist vision started not only from his repugnance for the nationalistic conflicts among European nations, but also from the fragmentary political situation in his own country which was plunged in confusion with factionalism and, especially Kleinstaaterei, which referred to the large number of small states and city-states during the Holy Roman Empire and the German Confederation. In Goethe's days, Germans had difficulty in developing their own national culture and identity and the development of domestic nationalism allowed Goethe to recognize and analyze the logic of nationalism. It goes without saying that this was a key factor in allowing him to invent the idea of world literature. Nevertheless, the important thing is that he lamented for the lack of a politicalcultural center where German authors would invent their national literature (see Pizer 216). Given Germany's lack of a strong national culture and identity, consequently, Goethe may as well surrender all hope of creating a national literature and as Pizer said the only probable alternative, to open to the 
possibility of a transnational literary modality (216). Goethe himself made a speech helping to verify this conjecture: "everywhere one hears and reads about the progress of the human race, about the further prospects for world and human relationship. However that may be on the whole, which it is not my office to investigate and closely determine, I nevertheless would personally like to make my friends aware that I am convinced a universal world literature is in the process of being constituted, in which an honorable role is reserved for us Germans" (Essays 225)

Goethe thought about the formation of world literature and the position of German literature in the constitution of world literature probably runs counter to René Wellek's description that world literature is "an ideal of the unification of all literatures into one literature where each nation would play its part in a universal concert" (221). In other words, Goethe's partiality to to German-language literature might be contrary to his own concept of world literature as a universal totality, one that transcends exclusive nationalisms. Thus world literature arising from the awakening of the German people is, in fact, most likely to be another name for nationalism, romantic nationalism. Hence, Pizer insists that Goethe has assumed an ambiguous attitude toward the concept of world literature. Despite of its universalist implication of "world," whenever talking about world literature, Goethe could not always put the issue of German nationalism out of his mind. While the notion of world literature is opposed to nationalism in that it is in some ways emerged from the German national situation, it is hard to say that it is never involved in nationalism. Maybe the universalist concept of world literature might be in league with particularist nationalisms. But this hypothesis does not mean that the universalist claims of world literature are not valid or only one between the world literature and the national literature should be chosen. Hence Goethe's idea of world literature is essentially both universal and particular.

What did Goethe really mean by saying "world"? What he thought is entirely different from what we now think. As indicated by his phrases like "a European, in fact a universal world literature" (Goethe, Essays 225) and "European, in other words, World Literature" (Goethe qtd. in Prendergast 3), Goethe identified world literature with European literature. In addition, considering his belief "that early works of Egyptian, Indian, and Chinese literature could only be viewed as 'curiosities' that lacked the potential to enhance the modern European's ethical and aesthetic acculturation" (see Pizer 217), all literatures being produced outside of Europe might be excluded from Goethe's list of world literature. Then, transnational interchange and traffic of cultures and literatures which has been advocated by the very idea of world literature would be only for European nations and peoples. Susan Bassnett suggests "although he eventually turned his attention to the literatures of continents beyond Europe, his coinage of the term Weltliteratur related to his views on Europe and in particular to his desire for an end to war" (21). Bassnett underlines that Goethe's remarks about world literature was related not to his comprehensive attention to the literatures of literatures beyond Europe, but to his anxieties about the national and cultural fragmentation of Europe. The problematics of the universal/particular of Goethe's paradigm of world literature belongs to a different realm from his individual political tendency or his "constantly shifting personality" (Damrosch 1) and it is not so much a matter of private choice or judgment between the two as it is the structural analysis of historical moment (not exactly chronological) that generate this type of universal/particular. There exists a common moment behind Goethe's ambiguity: cosmopolitan pacifism and nationalist partisanship, an ambiguity that makes it possible for the universal and the particular to coexist on the plane of immanence. Hence European imperialism opened the epistemological possibility of universalist politics of world literature, but on the other hand by limiting it to the European continent it brought back it into the particularist one: it functions as the ontological condition of the possibility for the immanent relationship itself between the universal and the particular. However, why did Edward W. Said insist that "the study of comparative literature originated in the period of high European imperialism and is irrecusably linked to it?" (43). This is a path that would lead us on to the analysis of relationship between comparative literature and European imperialist expansion.

As suggested by Goethe that "a universal world literature is in the process of being constituted" and that "a world literature has been in existence for some time is to some extent continuing and developing, still. Goethe recognized world literature not only as the portrayal or possibility of the future, but also as the real object of his observation. In other words, the idea of world literature is a cultural phenomenon that has actually begun visible in early nineteenth-century Europe, as well as a utopian ideal of Goethe himself. Ernst Elster, for instance, argues that Goethe does not intend his idea to imply cosmopolitan conversations among diverse cultures, but that he just "emphasizes that the international (literary) market is open" (Elster qtd. in Pizer 221). According to this view, Goethe is only a passive observer who witnesses that the scope of literary commerce expands from the nation to the world and not the active thinker who promotes more solidarity among nations. Elster's view, however, is worthy of note since it shows economic features of world literature as world literary market and this accounts for the presence of a world literature as a cultural phenomenon and paves the way to think about the relationship between world literature and nineteenth-century capitalism. David Damrosch also stresses that the network of world literature has a fundamentally economic character and suggests a correlation between world literature and modern capitalism by investigating how the idea of world literature is dealt with in Marx's and Engels's The Communist Manifesto: "The bourgeoisie has through its exploitation of the world market given a cosmopolitan character to production and consumption in every country ... All old-established national industries have been destroyed or are daily being destroyed ... In place of the old local and national seclusion and self-sufficiency, we have intercourse in every direction, universal inter-dependence of nations. And as in material, so also in intellectual production. The intellectual creations of individual nations become common property. National one-sidedness and narrow-mindedness become more and more impossible, and from the numerous national and local literatures, there arises a world literature" (The Communist 221; see also Prawer). By referring to Goethe's term, Marx and Engels described the process that national literatures as commodity are reorganized 
into global circulation. The difference between world literature and world market is that the latter is located in the sphere of material products while the former in spiritual and intellectual products. For Marx and Engels, world literature means the advent of quintessential modern literature and thus signs the beginning of modern capitalism and the world market as its economic base. To sum up, Goethe perceived the emergence of a world market of literature and then names it "world literature" and projected his own utopian desire on it.

The linkage of world literature and world market discloses the fact that the world literature as a sub-field of world market has something to do with another socio-economic factor: European imperialism. A capitalist world economy is "followed at the end of the 19th-century by the moment of imperialism, in which the limits of the national markets were burst and a kind of world-wide colonial system established" (Jameson, "Five Theses" 2). In this way, the world market is formed under colonialism, the process that European powers lend themselves to imperialist penetrations and owing to these invasions the market system of modern capitalism infiltrates into all parts of the world. Despite its obvious limits, however, European expansion offered Goethe some epistemological possibility of holding together individual European nations into the single Europe. The reason why he could call Europe "a world" is owing to the specific historical situation that allows him to see Europe as Identity. By enlarging the epistemological framework of European people from the nation to the world, imperialism produces the moment of being able to totalize and unify European nations. Goethe's and his world literature's two faces, desire for universalism and socio-economic substance as the smaller part of world market, are thus linked dialectically to both. Of note is that some scholars emphasize the influences of imperialism in Goethe's texts such as in his Faust and Wilhelm Meister: "some of his major works address a world that is being radically restructured by Europe's overseas adventures" (Noyes 443).

The emergence of imperialism brings about the radical transformation of the paradigm of "Otherness" in the epistemological framework of European literature. The stereotypical paradigm of the Other before the high imperial expansion began was the other European nation-state. In the nineteenth century peoples' greatest concern was the competition and rivalry between their nations and the establishment of their own unique nationalities through those competitions. For example, in Zola's La Débâcle, Germans are depicted as being "physically alien and terrifying, barbarous, uncivilized" (Zola qtd. in Jameson, "Modernism" 49). But as more and more the system of imperialism widens and strengthens, the axis of Otherness begins to be displaced from those national subjects to the unknown world outside Europe: for the overall picture of imperialism that transcends the competing relationship among European nations makes an appearance and hence a binary opposition between Europe and the rest, between the empires and the colonies, and between the First World and the Third World surfaces. The "Third World" is constituted as the far more radical otherness than any other European national subject (on the residual of this today, see, e.g., DeSousa, Henton, Ramanathan

<http://docs.lib.purdue.edu/clcweb/vol12/iss2/>). Further, "Third World" otherness establishes itself entirely as a substitute for the existing paradigms of otherness within European national paradigms. In Heart of Darkness, Joseph Conrad shows that the axis of otherness travels from the First World to the "Third World" through the episodes of Kurtz. The point that needs to be emphasized, here, is that such a displacement of the axis of otherness makes for the new dilemma or crisis of representation: "But this masking of one axis of otherness by a very different one, this substitution of rivalry for exploitation, and of a First World set of characters for a Third World presence, may be thought of as a strategy of representational containment ... Colonialism means that a significant structural segment of the economic system as a whole is now located elsewhere, beyond the metropolis, outside of the daily life and existential experience of the home country, in colonies over the water whose own life experience and life world - very different from that of the imperial power - remain unknown and unimaginable for the subjects of the imperial power ... No ... structural connections between that and this, between absent space and daily life in the metropolis" (Jameson, "Modernism" 49-51). In addition, the efforts Europe's empire building and its efforts to cover up the fact that there is a master/servant relationship make it more difficult to represent Third World otherness. Consequently, First World peoples are deprived of the paradigm of otherness itself and thus fail to deal with Third World otherness. This has a significant effect on the epistemological frame of European literature since it makes it no longer possible to make a mental map of the world-system: "its effects are representational effects, which is to say a systemic block on any adequate consciousness of the structure of the imperial system" (Jameson, "Modernism" 50).

This representational containment, however, does not exhaust all the epistemological possibilities. Rather, it opens up a certain unexpected possibility of cognitive mapping for the more radical otherness of the "Third World" makes the existing otherness within European nations no longer radical or even non-radical. This foregrounds the promotion of solidarity among the less radical Others. Confronted with the "Third World" beyond the First World, European nation-states begin to feel a sense of familial warmth and kinship with their neighboring - once rival and competing - states, the feeling that "we are all the same Europeans." This is a kind of ironic moment that colonialism helps to enhance collaborations and partnerships among European nations. Thanks to this restructuralization into a larger world including the "Third World" of the epistemological framework Goethe was able to represent Europe as a "single world." He could embrace all European nations within the same single category, Europe, by contrasting the European national Others with other worlds. The development of the imperial world-system including the world market allowed him to totalize European nations into a universal Identity. Considering the chaos of nineteenth-century Europe, without this epistemological transformation, it seems to be almost impossible to take and maintain some universalist attitude going beyond national interests and securities. Hence, I argue that the condition of possibility for the universalist politics of world literature is paradoxically the imperialist world-system. But this politics of uni- 
versalism entails an inevitable limit and cannot be an ultimate solution to the dilemma of representation because it fails to understand "Third World" otherness. It merely fastens internal elements together for the moment through the effects of containment given by the First/Third World representational dilemma. In the structure of his world literature paradigm, therefore, there is no other way than to declare "Europe" as a "world": "in Goethe's works . . . to be a citizen of the world is to live in a world increasingly determined by European overseas expansionism" (Noyes 448). John K. Noyes's argument suggests that Goethe failed to arrive at planetary universality. After all, the project of world literature might be an unfinished one limited to the boundary of Europe. Karl S. Guthke sees this in terms of a duality and he argues that Goethe has, on the one hand, a "global consciousness" that makes a special effort to include the new cultures, but on the other hand, he has a "pan-European humanism" that focuses its gaze on its own culture and on that of classical antiquity (454). Goethe's duality might be explained logically: the integration of the particular toward the universal could be done successfully only when depending on another hidden or excluded particular, namely the more radical otherness. Thus, it is the replacement of the axis of otherness that defines the dialectical play between the particular and the universal. There can never exist an a priori, absolute universalism: it is the kind of utopian virtuality and there are only limited, restrictive universalisms such as the idea of world literature. The development of comparative literature as a discipline is also dependent on the precisely this logic.

As I argue above, the intimate relationship between world literature and the imperial world-system suggests that comparative literature as a discipline might also be related to European expansion and hence comparative literature could not be founded as one of the modern European disciplines without nineteenth-century imperialism: the Other is necessarily needed to prepare the conditional situation on which universalist ideals are formulated. More specifically, "universal" categories as Europe can be assumed only if there is a more radical Otherness, namely the "Third World." However, this sort of universalist ideal encounters inevitably a serious difficulty: the more struggling to achieve its universalist ideal the more likely it is that comparative literature would strengthen the opposition between the First World and other worlds and thereby continues to neglect and exclude the peripheral Others. Said emphasized that world literature's and comparative literature's "practical meaning and operating ideology were that, so far as literature and culture were concerned, Europe led the way and was the main subject of interest" (45). In sum, the search for a universal culture early comparatists advocated was concentrated on the establishment of European universal culture. Of course, such a universal culture symbolizes the crisis-free serenity of an ideal realm standing above all political conflicts and tensions, "a kind of anthropological Eden in which men and women happily produced something called literature, and a world that Matthew Arnold and his disciples designated as the of 'culture,' where only 'the best that is thought and known' could be admitted" (Said 45). But from a formal' perspective, diagonally opposite to its utopian contents, it achieves its own disciplinary goal only by relying on "Third World" otherness because both the unification of European nations and the realization of an ideal "cultural" Eden could be carried out only when contrasting Europe as a totality with the "Third World."

Starting in the eighteenth century, the paradigm of comparison in the study of literature gained prominence world wide in the twentieth century. Because globalization and its extended communication network made all kinds of repressed minority groups come into sight, it became standard to describe the relations among culturally different groups. Comparative literature was also required to map out diverse constructions of the category of the literary in different cultures and to draw a consented sense of the nature and function of literature cross-culturally. For example, Franco Moretti's, David Damrosch's, Pascale Casanova's, etc. scholarship are such attempts to theorize world literary production. Such scholarship challenges the limitation of national literatures and establishes the model of "world literatures" for thinking about literature in global terms. This global comparativism, however, may be little more than a return of Eurocentric assumptions if it means merely an expansion of the disciplinary scale of comparative literature and world literature from Europe to the world without reflecting upon the methodology of comparativism (on this, see, e.g., Boruszko and Tötösy de Zepetnek; Grishakova, Boldrini, Reynolds; Juvan; Tötösy de Zepetnek and Vasvári). Indeed, I posit that proponents of world literature models are allied with a deep suspicion of the notion that modern European forms spread out to the rest world unilaterally. I am suggesting that we should rethink the methodology of comparative literature in order not to reiterate its past imperial perspective. I find our renewed comparativism to be a performative action of deconstructing the existing grounds of comparison and thereby developing and recovering radical others in the forms of literature, not the derivative one of modern European's. Thus, the point in world literature politics is not a full theorization of world literary topography, but a ceaseless critique of proving the impossibility of totalized conceptualizing world literature and speculating about the historical constructedness of the methodological criteria of comparison. I believe that the absolute universalist category does not exit. The universal is not a fixed conceptual substance, but rather a moment of openness, which can be achieved in the very midst of continuous comparativist practices, or it is the openness toward the potential space where the more universal universalism could make its appearance. The building and the politics and practice of world literature understood as world literatures must be characterized by boundlessness and limitlessness in order to achieve an understanding and practice of the universal and planetary.

\section{Works Cited}

Anderson, Benedict. Imagined Communities: Reflections on the Origin and Spread of Nationalism. London: Verso, 1991.

Bassnett, Susan. Comparative Literature: An Introduction. Oxford: Blackwell, 1993. 
Boruszko, Graciela, and Steven Tötösy de Zepetnek, eds. New Work about World Literatures. Special Issue CLCWeb: Comparative Literature and Culture 15.6 (2013): <http://docs.lib.purdue.edu/clcweb/vol15/iss6/>.

Chow, Rey. The Age of the World Target: Self-Referentiality in War, Theory, and Comparative Work. Durham: Duke UP, 2006.

Chow, Rey. "In the Name of Comparative Literature." Comparative Literature in the Age of Multiculturalism. Ed. Charles Bernheimer. Baltimore: Johns Hopkins UP, 1995. 107-16.

Chow, Rey. "How (the) Inscrutable Chinese Led to Globalized Theory." PMLA: Publications of the Modern Language Association of America 116.1 (2001): 69-74.

Damrosch, David. What is World Literature? Princeton: Princeton UP, 2003.

DeSousa, Valerian, Jennifer E. Henton, and Geetha Ramanathan, eds. New Modernities and the "Third World." Thematic Issue CLCWeb: Comparative Literature and Culture 12.2 (2010): <http://docs.lib.purdue.edu/clcweb/vol12/iss2/>.

Elster, Ernst. Prinzipien der Literaturwissenschaft. Halle: Max Niemayer, 1897-1911. 2 vols.

Gellner, Ernest. Thought and Changes. Chicago: U of Chicago P, 1978.

Goethe, Johann Wolfgang von. Essays on Art and Literature. Trans. Ellen von Nardoff and Ernest von Nardoff. Princeton: Princeton UP, 1994

Grishakova, Marina, Lucia Boldrini, and Matthew Reynolds, eds. New Work in Comparative Literature in Europe. Special Issue CLCWeb: Comparative Literature and Culture 15.7 (2013): <http://docs.lib.purdue.edu/clcweb/vol15/iss7/>.

Jameson, Fredric. "A Note on Reification in Hegel's Logic." Critical Quarterly 50.3 (2008): 33-42.

Jameson, Fredric. "Five Theses on Actually Existing Marxism." Monthly Review 47.11 (1996): 1-10.

Jameson, Fredric. "Modernism and Imperialism." Nationalism, Colonialism, and Literature. Ed. Terry Eagleton, Fredric Jameson, and Edward W. Said. Minneapolis: Minnesota UP, 1990. 43-68.

Jameson, Fredric. "Notes on Globalization as a Philosophical Issue." The Cultures of Globalization. Ed. Fredric Jameson and Masao Miyoshi. Durham: Duke UP, 1998. 54-80.

Jameson, Fredric. "Globalization and Political Strategy." New Left Review 4 (2000): 49-68.

Juvan, Marko, ed. World Literatures from the Nineteenth to the Twenty-first Century. Special Issue CLCWeb: Comparative Literature and Culture 15.5 (2013): <http://docs.lib.purdue.edu/clcweb/vol15/iss5/>.

Marx, Karl, and Frederick Engels. The Communist Manifesto. Ed. Eric J. Hobsbawm. London: Verso, 1998.

Noyes, John K. "Goethe on Cosmopolitanism and Colonialism: Bildung and the Dialectic of Critical Mobility." Eighteenth-Century Studies 39.4 (2006): 443-65.

Pizer, John. "Goethe's 'World Literature' Paradigm and Contemporary Cultural Globalization." Comparative Literature 52.3 (2000): 213-27.

Prawer, S.S. Karl Marx and World Literature. London: Verso, 1976.

Prendergast, Christopher. "The World Republic of Letters." Debating World Literature. Ed. Christopher Prendergast. London: Verso, 2004. 1-25.

Said, Edward W. Culture and Imperialism. New York: Vintage Books, 1994.

Sakai, Naoki. "Modernity and Its Critique: The Problem of Universalism and Particularism." Postmodernism and Japan. Ed. Masao Miyoshi and H.D. Harootunian. Durham: Duke UP, 1989. 93-122.

Strich, Fritz. Goethe and World Literature. London: Routledge \& Kegan Paul, 1949.

Tötösy de Zepetnek, Steven, and Louise O. Vasvári. "About the Contextual Study of Literature and Culture, Globalization, and Digital Humanities." Companion to Comparative Literature, World Literatures, and Comparative Cultural Studies. Ed. Steven Tötösy de Zepetnek and Tutun Mukherjee. New Delhi: Cambridge UP India, 2013. 335.

Wallerstein, Immaneul. "The National and the Universal: Can There Be Such a Thing as World Culture." Culture, Globalization, and the World-System: Contemporary Conditions for the Representation of Identity. Ed. Anthony D. King. Minneapolis: Minnesota UP, 1997. 91-106.

Wellek, René. A History of Modern Criticism: 1750-1950. New Haven: Yale UP, 1955.

Author's profile: Dongho Cha is working toward his $\mathrm{PhD}$ in English literature at the University of Illinois. His interests in scholarship include modern Korean literature and culture, twentieth-century Asian American literature, contemporary poetry, and literary theory and aesthetics. His publications include "Sense-Making Sound: Agamben, Longenbach, and the Question of Poetic Meaning," Philosophy and Literature (2014) and "Wishing for a Home: Race, Class, and Global Capitalism in Theresa Hak Kyung Cha's Dictée and Se-Hüi Cho's A Little Ball Launched by a Dwarf," Modern Language Notes (2014). E-mail: <donghocha3@gmail.com> 